University of Nebraska - Lincoln

DigitalCommons@University of Nebraska - Lincoln

USDA National Wildlife Research Center - Staff Publications
U.S. Department of Agriculture: Animal and Plant Health Inspection Service

2020

\title{
Effects of brodifacoum and diphacinone exposure on four species of reptiles: tissue residue levels and survivorship
}

\author{
Richard E. Mauldin \\ United States Department of Agriculture,,Richard.E.Mauldin@usda.gov \\ Gary W. Witmer \\ USDA-APHIS-Wildlife Services. National Wildlife Research Center, gary.w.witmer@usda.gov
}

\author{
S. A. Shriner \\ USDA/APHIS/WS National Wildlife Research Center, susan.a.shriner@aphis.usda.gov \\ Rachael S. Moulton \\ USDA APHIS NWRC \\ Katherine E. Horak \\ USDA APHIS NWRC, katherine.e.horak@usda.gov \\ Follow this and additional works at: https://digitalcommons.unl.edu/icwdm_usdanwrc \\ Part of the Natural Resources and Conservation Commons, Natural Resources Management and \\ Policy Commons, Other Environmental Sciences Commons, Other Veterinary Medicine Commons, \\ Population Biology Commons, Terrestrial and Aquatic Ecology Commons, Veterinary Infectious Diseases \\ Commons, Veterinary Microbiology and Immunobiology Commons, Veterinary Preventive Medicine, \\ Epidemiology, and Public Health Commons, and the Zoology Commons
}

Mauldin, Richard E.; Witmer, Gary W.; Shriner, S. A.; Moulton, Rachael S.; and Horak, Katherine E., "Effects of brodifacoum and diphacinone exposure on four species of reptiles: tissue residue levels and survivorship" (2020). USDA National Wildlife Research Center - Staff Publications. 2367.

https://digitalcommons.unl.edu/icwdm_usdanwrc/2367

This Article is brought to you for free and open access by the U.S. Department of Agriculture: Animal and Plant Health Inspection Service at DigitalCommons@University of Nebraska - Lincoln. It has been accepted for inclusion in USDA National Wildlife Research Center - Staff Publications by an authorized administrator of DigitalCommons@University of Nebraska - Lincoln. 


\title{
Effects of brodifacoum and diphacinone exposure on four species of reptiles: tissue residue levels and survivorship
}

\author{
Richard E Mauldin, $\odot$ Gary W Witmer, Susan A Shriner, Rachael S Moulton \\ and Katherine E Horak*
}

\begin{abstract}
BACKGROUND: Anticoagulant rodenticides are used worldwide to control pest rodent species. However, the risks posed to nontarget reptiles have not been well characterized. In this study, 46 giant ameivas (Ameiva ameiva), 39 boa constrictors (Boa constrictor), 33 wood turtles (Rhinoclemmys pulcherrima), and 47 green iguanas (Iguana iguana) were orally dosed with one of two levels of either diphacinone or brodifacoum anticoagulant in propylene glycol solutions. Dosages were derived using daily food intake (DFI) equations, converting DFI to an equivalent anticoagulant bait amount and gavaging the solution volume needed to deliver the quantity of anticoagulant in that amount of bait. Animals were dosed on days $\mathbf{0}$ and $\mathbf{7}$ and monitored for a further 7 days for signs of anticoagulant intoxication and differences in behaviors and postures. At necropsy on day 14, animals were examined for thoracic and abdominal bleeding, and both tissue and organ samples were taken for histology. Liver and wholebody anticoagulant residues were assessed.
\end{abstract}

RESULTS: No turtles or boas died due to anticoagulant exposure. However, anticoagulant intoxication was suspected in one iguana dosed with brodifacoum. A few treated ameivas died but exhibited no hemorrhaging. Liver residue levels were higher than whole-body remainder residue levels for all species. Unlike the other species, turtles had higher diphacinone residue levels than brodifacoum.

CONCLUSION: Turtles and boas exhibited a relative insensitivity to diphacinone and brodifacoum, while the lizards appeared to be somewhat more sensitive to these compounds. This study provides data for future assessments of the risks to these species associated with anticoagulant use.

Published 2019. This article is a U.S. Government work and is in the public domain in the USA.

Keywords: brodifacoum; diphacinone; iguana; giant ameiva; boa constrictor; wood turtle; residue; reptile; anticoagulant; behavior

\section{INTRODUCTION}

The introduction of rodents and other non-native mammals to island ecosystems poses a serious risk to native species. ${ }^{1,2}$ These native species have often evolved without pressure from predators and therefore invasive rats frequently cause a precipitous decline in population size, leading to these species being listed as threatened and endangered or extinct. ${ }^{3,4}$ Moreover, rodents cause serious damage to agricultural crops and pose a threat to human health through the spread of disease. ${ }^{5}$ Because of these negative impacts there has been a concerted effort to control rodent populations and eradicate introduced rodents from islands. ${ }^{1,6,7}$ Anticoagulant rodenticides are the mainstay for these rodent control operations.

Although numerous studies and surveillance programs have been done to assess the risks and exposure of non-target animals to anticoagulant rodenticides, little is known about risks posed to non-target reptiles. ${ }^{8-12}$ Reports of reptile mortality associated with routine brodifacoum baiting operations are uncommon. In two separate observations, single dead moko skinks (Oligosoma moco) were found near baiting stations at two locations in New Zealand. ${ }^{13}$ One skink contained a brodifacoum residue (probably whole body) of $0.82 \mu \mathrm{g} \mathrm{g}^{-1}$, while analysis of stomach contents in another skink showed a concentration of $19 \mu \mathrm{g} \mathrm{g}^{-1}$ of pindone. Necropsy of the second skink found blood clots ventral and caudal to the heart. ${ }^{13} \mathrm{~A}$ single Northland green gecko (Naultinus grayii) was found dead after pindone baiting operations near Boundary Stream, New Zealand and contained $0.52 \mu \mathrm{g} \mathrm{g}^{-1}$ pindone. This level of pindone was similar to the concentration found in the baits. ${ }^{13}$ During a 2-month rabbit eradication program on Round Island, Mauritius using brodifacoum pelleted baits ( $20 \mathrm{\mu g} \mathrm{g}^{-1}$ brodifacoum a.i.), Merton ${ }^{14}$ noted that of the several local species of skinks and geckos, only Telfair's skinks (Leiolopisma telfairii) routinely consumed bait pellets. After 3 weeks of bait exposure, dead skinks were observed, with increasing mortality over the next 5 weeks, after which no

\footnotetext{
Correspondence to: KE Horak, USDA APHIS WS National Wildlife Research Center, 4101 LaPorte Ave, Fort Collins, Colorado 80521, USA. E-mail: katherine. e.horak@usda.gov
}

USDA APHIS WS National Wildlife Research Center, Fort Collins, CO, USA 
additional dead skinks were found. Over 100 dead Telfair's skinks (out of an estimated population of 5000) were found, primarily during the warmest parts of the day and on the warmest days.

Pitt et al. ${ }^{6}$ collected geckos (Lepidodactylus lugubris and Hemidactylus frenatus) on five separate occasions both pre- and postbrodifacoum bait application spanning a 2-month period on Palmyra Atoll. All pre-treatment brodifacoum residue levels were less than the method limit of detection, while the post-treatment residues ranged from 0.012 to $067 \mu^{-1} \mathrm{~g}^{-1}$. Bettink ${ }^{15}$ collected eight dead King's skink (Egernia kingii) over a 3-month period following baiting with a brodifacoum $\left(0.05 \mathrm{mg} \mathrm{kg}^{-1}\right)$ bait on Penguin Island, Western Australia, with hemorrhaging the likely cause of death. Following flocoumafen baiting in the Chafarinas Islands (Mediterranean), Sanchez-Barbudo ${ }^{16}$ found one dead horseshoe whip snake (Hemorrhois hippocrepis) with a liver flocoumafen concentration of $0.54 \mu_{\mathrm{g} \mathrm{g}^{-1}}$ w.w.

Despite these reports of anticoagulant exposure in reptiles, Hoare and Hare ${ }^{17}$ found a lack of information about the potential risks of anticoagulants to non-target reptiles in a review of brodifacoum use. Lohr and Davis ${ }^{18}$ found a similar shortage of reptilespecific data when reviewing anticoagulant bait use in Australia. Continued studies examining non-target risk to reptiles following anticoagulant treatment were also advocated by Herrera et al. ${ }^{19}$ following a study monitoring survivorship in two lizard species (Ameiva desechensis and Anolis desechensis) on Desecheo Island (Puerto Rico) before, during, and after baiting with brodifacoum. No mortality was found in either species.

Very few laboratory studies have been done to determine the lethality or physiological effect of anticoagulants on reptiles. Brooks and colleagues ${ }^{20}$ orally dosed brown tree snakes (Boiga irregularis) with warfarin or diphacinone and determined that the $\mathrm{LD}_{50}$ was $40 \mathrm{mg} \mathrm{kg}^{-1}$ and $40-80 \mathrm{mg} \mathrm{kg}^{-1}$, respectively; however, none of the animals showed signs of distress and there was no internal bleeding noted upon necropsy. ${ }^{20}$ In a separate study of McCann's skinks (Leiolopisma maccannii), animals consumed brodifacoum bait but there was no mortality in this short 2-day test. ${ }^{21}$ Because of their widespread use and the lack of data on the effect of anticoagulants on reptile species, additional controlled studies need to be done on more species within this vertebrate class.

As an initial step, the objective of this study was to determine potential non-target risks in four reptile species representing various reptile taxa that might be encountered in anticoagulant-based insular rodent eradication efforts, especially in the western hemisphere. Giant ameivas (Ameiva ameiva), boa constrictors (Boa constrictor), Central American wood turtles (Rhinoclemmys pulcherrima), and green iguanas (Iguana iguana) were orally dosed with one of two levels of the anticoagulants diphacinone or brodifacoum. Species were chosen to represent different reptilian taxa and primary dietary consumption types (carnivore, herbivore, etc.) and associated digestive adaptations to determine if anticoagulants interacted differently with dietary type (boas are obligate carnivores, turtles are omnivores, ameivas are insectivores, and iguanas are primarily herbivores). Animals were observed for signs of intoxication, comparing various behaviors and resting postures pre and post treatment to assess non-lethal but toxicant-related behavioral effects.

\section{MATERIALS AND METHODS}

\subsection{Animal care and housing}

\subsubsection{General}

All animals were purchased from commercial suppliers. Boas were and wood turtles were wild-caught. On arrival, all animals were weighed, sexed, and hydrated by placement in shallow tubs containing water.

Size-appropriate PVC hides (PVC pipe cut lengthwise) were provided for all animals except large and small boas (see boa constrictor section), and water was provided in bowls ad libitum. Turtle and boa cage floors were initially covered with newspaper, while lizard cage floors were covered with aspen chips (SaniChips, PJ Murphy; Montville, NJ, USA). For turtles and lizards, newspaper was also taped over the side of the cage facing the open room to visually occlude the observers.

All animals were housed in an environmentally controlled room measuring $3.75 \times 14.1 \mathrm{~m}$ maintained at $\approx 28{ }^{\circ} \mathrm{C}$ (for turtles and boas) or $\approx 26{ }^{\circ} \mathrm{C}$ (ameivas, iguanas) and $60-65 \%$ relative humidity with a $12 \mathrm{~h}$ light/12 h dark photocycle (lights on at $0700 \mathrm{~h}$ Mountain Standard Time (MST), off at $1900 \mathrm{~h} \mathrm{MST).} \mathrm{A} \mathrm{data} \mathrm{logger}$ (Edstrom Industries, Waterford, WI, USA) placed in center of the room continuously monitored temperature, humidity, and photoperiod. Two large box fans kept the room air circulating and both temperatures and humidity homogeneous. Turtles, iguanas, and ameivas received additional light and basking heat by incandescent $40 \mathrm{~W}$ bulbs mounted to the rear or sides of their cages using clamp lights with reflectors. For iguanas and ameivas, aquarium fronts were covered with newspaper to minimize animal reactions to animal care staff and observers.

The study was performed under protocol QA-1434 and approved by the National Wildlife Research Center Institutional Animal Care and Use Committee. All methods were carried out in accordance with the relevant guidelines and regulations.

Turtles. Following receipt, each turtle was placed singly in a clear, polycarbonate box measuring $20.3 \mathrm{~cm}$ (height, $\mathrm{H}$ ) $\times 40.6 \mathrm{~cm}$ (width, W) $\times 55.9 \mathrm{~cm}$ (length, L) with a weighted wire top. Individual cages were then mounted into a rack (Techniplast, West Chester, PA, USA). Hides were located in the front of the cage.

Water was provided in a small shallow bowl ad lib and food (a pre-weighed mixture of mixed greens, carrots, peas, strawberries, and celery) was provided at $0930 \mathrm{~h}$ in a shallow Petri dish which was removed and reweighed prior to lights off at $\approx 1800 \mathrm{~h}$. Turtles were kept in quarantine for 54 days and weighed monthly to ensure acclimation and stable/increasing body weight prior to treatment.

Boa constrictors. On arrival, boas ranged in weight from 0.34 to $5.0 \mathrm{~kg}$. Each boa was sprayed with a miticidal Ivermectin solution and housed separately, with the largest boas $(>2 \mathrm{~kg}$ ) being housed in large, modified rabbit cages $(45.7 \mathrm{~cm}$ $\mathrm{H} \times 76.2 \mathrm{~cm} \mathrm{~W} \times 76.2 \mathrm{~cm} \mathrm{~L}$ ). Each cage was then placed in a rack (Allentown Caging Equipment, Allentown, PA, USA). Grated cage doors were covered with cardboard to prevent escape or injury. Undercage heating $\left(\approx 34.5^{\circ} \mathrm{C}\right)$ was provided by a $15.2-\mathrm{cm}$ wide band of mylar substrate heat tape taped across the underside of the rear of the cage (Ultratherm, Scotland, UK).

Medium-sized boas $(0.7-1.99 \mathrm{~kg})$ were housed individually in cages $(23.5 \mathrm{~cm} \mathrm{H} \times 43.2 \mathrm{~cm} \mathrm{~W} \times 64.8 \mathrm{~cm} \mathrm{~L})$ which were then loaded in a rack (Freedom Breeder, Turlock, CA, USA). Undercage heating was provided as previously described for large boas. For medium boas, large $(3 \mathrm{~L}, 8.9 \mathrm{~cm} \mathrm{H} \times 27.3 \mathrm{~cm}$ diameter $)$ and medium (1 L, $2.9 \mathrm{~cm} \mathrm{H} \times 22.2 \mathrm{~cm}$ diameter) plastic dog water bowls with a hole cut in the side provided both water and a hiding space under of the bowl. Newspaper was initially used as bedding. Boas were fed weekly with size-appropriate frozen/thawed mice or rats, and were held in observation/quarantine for 14 days and weighed once over that period. 
Iguanas. Newly arrived iguanas ranged in weight from 0.053 to $0.59 \mathrm{~kg}$. The ten largest iguanas $(0.385-0.59 \mathrm{~kg})$ were kept in $15 \mathrm{gal}(56.8 \mathrm{~L})$ aquaria $(30.5 \mathrm{~cm} \mathrm{H} \times 30.5 \mathrm{~cm} \mathrm{~W} \times 61 \mathrm{~cm} \mathrm{~L})$. Smaller iguanas $(0.053-0.33 \mathrm{~kg})$ were kept in $10 \mathrm{gal}(37.9 \mathrm{~L})$ aquaria $(30.5 \mathrm{~cm} \mathrm{H} \times 25.4 \mathrm{~cm} \mathrm{~W} \times 50.8 \mathrm{~cm} \mathrm{~L})$. All aquaria had wire mesh tops weighted to prevent escape. Aspen chips (Sani-Chips, PJ Murphy, Montville, NJ, USA) were initially used as bedding.

Iguanas were fed a pre-weighed mixture of mixed greens, squash, sweet potatoes, peas, melons, mangos, papaya, bananas, apples, cooked rice/pasta, and whole wheat bread. Feed was placed in a Petri dish at the front of the aquarium and handled as described for turtles. Iguanas were held in quarantine for 21 days.

Ameivas. Ameivas initially ranged in weight from 0.013 to $0.159 \mathrm{~kg}$. As described in the iguana section, the largest ten ameivas $(0.095-0.159 \mathrm{~kg})$ were housed in $15 \mathrm{gal}$ aquaria, while the remaining ameivas $(0.013-0.089 \mathrm{~kg}$ ) were housed in $10 \mathrm{gal}$ aquaria. Ameivas were fed an insectivorous diet of crickets, waxworm larvae, and several roach species, and were kept in quarantine for 13 days.

\subsubsection{Behavior/posture observations}

We selected a set of behaviors commonly associated with either normal conditions or distress in reptiles a priori, and postures which might also be used to distinguish normal from abnormal behavior were noted during the quarantine phase of the study. Behavioral observations were made throughout the quarantine and treatment phases of the study as unobtrusively as possible. For turtles and both lizard species, the behaviors watched for were (i) sleeping, (ii) inactive (awake), (iii) hyperactive, (iv) climbing, (v) walking, (vi) tremors, (vii) comatose, and (viii) eating. Sleeping animals generally opened their eyes while being observed; animals that did not do so usually responded to a light tapping of the cage. Animals that did not respond at this point but breathing were gently prodded and if unresponsive were noted as comatose. Hyperactivity was defined as continuous, highly excited movement as opposed to normal locomotion. Boas were watched for the same behaviors with writhing substituted for walking as an indication of discomfort, and sleeping (difficult to determine) omitted. In turtles, the activity referred to as 'pumping' (limbs rapidly in and out) was included as a posture, but could also have been included as a behavior. The postures noted are summarized in Table 1. During the quarantine phase, animals were observed twice daily at $0930 \mathrm{~h}$ and $1500 \mathrm{~h}$.

\subsection{Dosing}

For all animals, bedding was removed prior to the beginning of the study and replaced with light-brown indented kraft paper $\left(24^{\prime \prime}\right.$ roll $(61 \mathrm{~cm})$; Uline, Dallas, TX, USA) visualization of possible emesis/regurgitation or bleeding following treatment. Approximately $24 \mathrm{~h}$ prior to treatment, all animals were fasted, weighed, and weight-ranked. Using the online randomization program Research Randomizer (http://www.randomizer.org/about.htm), all animals were randomly assigned to one of the five treatment groups: control, diphacinone $1 \times$ (diphacinone low), diphacinone 10× (diphacinone high), brodifacoum 1× (brodifacoum low), brodifacoum 10x (brodifacoum high). During the dosing session, each animal was re-weighed in order to calculate the mass of food each animal would hypothetically consume and the equivalent anticoagulant dosage. Experimental numbers by species and sex are shown in Table 2.

As a first attempt at estimating toxicant intake for species with such significant dietary and size differences, dosages were calculated using dry matter ingestion rates $\left(\mathrm{g} \mathrm{day}^{-1}\right)$ for herbivorous and insectivorous iguanids ${ }^{22}$ (Table 3 ). For turtles, boa constrictors, and ameivas (represented by the equation for insectivorous iguanids), the anticoagulant dose was calculated as $\mathrm{FI}=0.013 \mathrm{Wt}^{0.773}$ where $\mathrm{FI}$ is the food ingested in grams (dry weight per day) and $\mathrm{Wt}$ is the body weight of the animal in grams. For iguanas, a largely herbivorous iguanid, the equation used was $\mathrm{FI}=0.019 \mathrm{Wt}^{0.841}$. Thus, animals were administered a dose of diphacinone or brodifacoum equivalent to the quantity of the compound they would be exposed to if only brodifacoum or diphacinone baits $(0.0025 \%$ and $0.005 \%$ active ingredient, respectively) was consumed for 1 day. This quantity represents the $1 \times$ dose of either toxicant (referred to as low dose), and is a dose which likely overestimates what the animals would consume (if they consumed bait directly at all). To investigate a 'worst case scenario', the animals were also administered ten times that quantity (referred to as high dose).

Each gavage solution was prepared just prior to dosing by weighing the largest reptile of each species and calculating the maximal amount of anticoagulant to be consumed using the appropriate equation described previously, in a volume of no more than $0.5 \mathrm{~mL}$ propylene glycol (PG; Sigma-Aldrich, St. Louis, MO, USA) for turtles or $1 \mathrm{~mL}$ for the other species (larger boas received $>1 \mathrm{~mL}$ volumes). The appropriate amount to dose the entire group (plus overage) was weighed out and dissolved in $25 \mathrm{~mL}$ PG along with $\approx 7 \mathrm{mg}$ of erioglaucine (a non-toxic blue dye; Sigma-Aldrich), which was added to facilitate identification of any emesis or regurgitation. Control animals received a gavage of PG equivalent to the treatment volume administered to an animal of that weight. Dosing solution concentrations, animal weight ranges at first treatment, and dosage ranges for each species for both anticoagulants at both concentrations are summarized in Table 3 .

All animals were dosed via oral gavage on days 0 and 7 with the appropriate anticoagulant in PG. To gavage, each reptile was held firmly and its mouth gently opened and held open using an avian oral speculum. Ball-tipped feeding needles were used to gavage lizards and turtles, while red rubber catheter tubing was used with boas. After the first dosing, animals were observed at least four times daily (every $2 \mathrm{~h}$ ) as a general wellness check and for signs

\begin{tabular}{|c|c|c|c|c|c|c|}
\hline \multirow[b]{2}{*}{ Species } & \multirow[b]{2}{*}{ Up on front legs } & \multirow[b]{2}{*}{ Limbs near body } & Posture & \multirow[b]{2}{*}{ Body curled up } & \multirow[b]{2}{*}{ Body extended } & \multirow[b]{2}{*}{ Pumping } \\
\hline & & & Limbs extended & & & \\
\hline Turtles & & $x$ & $x$ & & & $x$ \\
\hline Boa constrictors & & & & $x$ & $x$ & \\
\hline Iguanas & $x$ & $x$ & $x$ & $x$ & & \\
\hline Ameivas & $x$ & $x$ & $x$ & $x$ & & \\
\hline
\end{tabular}


Table 2. Experimental animal numbers $(n)$ and sex ratios by treatment

\begin{tabular}{|c|c|c|c|c|c|c|c|c|c|}
\hline \multirow[b]{3}{*}{ Gavage } & \multirow[b]{3}{*}{ Sex } & & & \multicolumn{2}{|c|}{ Species } & & & & \\
\hline & & \multicolumn{2}{|c|}{ Turtles } & \multicolumn{2}{|c|}{ Boa constrictors } & \multicolumn{2}{|c|}{ Iguanas } & \multicolumn{2}{|c|}{ Ameivas } \\
\hline & & M & $\mathrm{F}$ & M & $\mathrm{F}$ & M & $\mathrm{F}$ & M & $\mathrm{F}$ \\
\hline Control (PG) & & 5 & 3 & 3 & 4 & 7 & 2 & 5 & 4 \\
\hline Low brodifacoum & & 5 & 5 & 3 & 5 & 6 & 3 & 5 & 4 \\
\hline High brodifacoum & & 2 & 2 & 3 & 5 & 8 & 2 & 5 & 4 \\
\hline Low diphacinone & & 1 & 6 & 4 & 4 & 6 & 3 & 6 & 4 \\
\hline High diphacinone & & 2 & 2 & 3 & 5 & 7 & 3 & 5 & 4 \\
\hline
\end{tabular}

Table 3. Dosing solution concentrations, first treatment animal weight ranges, and dosage ranges for each of four reptile species for both brodifacoum (B) and diphacinone (D) at two concentrations

\begin{tabular}{|c|c|c|c|c|c|}
\hline Species & Toxicant & Level & Gavage solution $\left(\mu \mathrm{g} \mathrm{mL}^{-1}\right)$ & Weight range $(\mathrm{kg})$ & Dosage range $\left(\mu \mathrm{g} \mathrm{kg}^{-1}\right)$ \\
\hline \multirow[t]{4}{*}{ Wood turtles } & B & $1 \times$ & 160.4 & $0.253-0.902$ & $91.4-119$ \\
\hline & B & $10 x$ & 1605 & $0.315-0.915$ & $887.7-1131$ \\
\hline & $\mathrm{D}$ & $1 \times$ & 301 & $0.194-0.965$ & $166.5-234.4$ \\
\hline & $\mathrm{D}$ & $10 x$ & 3070 & $0.322-0.778$ & $1761-2151$ \\
\hline \multirow[t]{4}{*}{ Boa constrictors } & B & $1 \times$ & 160.4 & $0.480-5.190$ & $59.8-102.7$ \\
\hline & B & $10 x$ & 1605 & $0.500-4.290$ & $625-1018$ \\
\hline & $\mathrm{D}$ & $1 \times$ & 308 & $0.470-3.730$ & $125-198$ \\
\hline & $\mathrm{D}$ & $10 x$ & 3070 & $0.370-4.440$ & $1186-2085$ \\
\hline \multirow[t]{4}{*}{ Ameivas } & B & $1 \times$ & 20.3 & $0.036-0.142$ & $134-183$ \\
\hline & B & $10 x$ & 201.5 & $0.039-0.137$ & $1339-1781$ \\
\hline & $\mathrm{D}$ & $1 \times$ & 41 & $0.044-0.141$ & $239.2-311.8$ \\
\hline & $\mathrm{D}$ & $10 x$ & 401.4 & $0.036-0.104$ & $2508-3185$ \\
\hline \multirow[t]{4}{*}{ Iguanas } & B & $1 \times$ & 123 & $0.070-0.412$ & $241.7-320.76$ \\
\hline & B & $10 x$ & 1200 & $0.063-0.491$ & $2293-3178$ \\
\hline & $\mathrm{D}$ & $1 \times$ & 214 & $0.055-0.409$ & $421.3-581.2$ \\
\hline & $\mathrm{D}$ & $10 x$ & 2090 & $0.056-0.459$ & 4039-5635 \\
\hline
\end{tabular}

of anticoagulant intoxication (i.e. hemorrhaging) or distress. Observations decreased to two times daily after that. A 7-day observation period would likely allow sufficient time for symptoms to develop.

Since most of the animals used in this study were wild-caught, it was likely that the stress of continued captivity could cause mortality in some individuals. To distinguish stress-induced morality from lethal intoxication, we determined prior to the start of the study that only animals that either (i) displayed exterior (visible) or interior hemorrhaging (on necropsy) with histological confirmation of coagulopathy or microangiopathy, or (ii) died after dosing but prior to the end of the study and showing obvious evidence of hemorrhaging would be counted as having experienced lethal intoxication. Additional sources of external bleeding could be loss of a claw or tooth/oral damage. The latter conditions were occasionally seen in both ameivas and iquanas.

Two weeks (day 14) after the first dosing, all animals were euthanized, necropsied, and examined for gross signs of anticoagulant intoxication. Both the thoracic and abdominal cavities were closely examined for frank signs of bleeding and coagulopathy or other abnormalities, which included anything related to coagulation but also disease, health, and nutritional status. Tissue and organ samples were also removed for subsequent histopathology (see below). Livers and remaining carcasses were frozen for subsequent high-pressure liquid chromatography (HPLC) anticoagulant residues analysis. Turtle carcasses were removed from their shells prior to freezing.

\subsection{Histopathology}

During necropsy, samples of heart muscle, skeletal muscle, liver, spleen, kidney, alimentary tract, and mesentery were removed and examined for bruising, frank blood, and any other observable abnormalities. Tissues were then stored in $10 \%$ neutral buffered formalin for subsequent histological examination by Northwest Zoopath (Monroe, WA, USA).

\subsection{Analytical determination of diphacinone and brodifacoum in dosing solutions}

To determine anticoagulant concentration in dosing solutions, methanol was added to the solution and the sample was sonicated. The samples were then diluted into the linear range of the instrument (reverse phase-high pressure liquid chromatography, RP-HPLC) in a solution of $50 \% 5 \mathrm{mM}$ tetrabutylammonium perchlorate in $\mathrm{pH} 8.56 \mathrm{mM}$ phosphate buffer $/ 50 \%$ methanol 
and filtered into vials for RP-HPLC analysis according to Pitt et al. ${ }^{6}$ with the following modifications: diphacinone and brodifacoum concentrations were determined using an Agilent 1100 series HPLC system and Luna C18, $3.0 \mu \mathrm{m}, 50 \times 3.0 \mathrm{~mm}$ column (Phenomenex, Torrance, CA, USA). Diphacinone and brodifacoum were detected via ultraviolet absorbance at 285 and $265 \mathrm{~nm}$, respectively.

\subsection{Analytical determination of tissue residue levels}

Residue levels of both brodifacoum and diphacinone were determined in liver and whole-body remainder (the entire carcasses without the liver and tissues removed for histopathology, as well as turtle carcasses with shells removed) by HPLC. Specifically, livers were homogenized using liquid nitrogen with a mortar and a pestle. The carcasses were skinned and processed through a meat grinder followed by liquid nitrogen milling (SPEX Certiprep). Samples of $500 \mathrm{mg}$ of each homogenate were weighed into Teflon microwave tubes and then heated to $51.7^{\circ} \mathrm{C}$. Each sample was analyzed twice: once for diphacinone residues and again for brodifacoum residues.

Chlorophacinone and difenacoum were added to each sample to serve as surrogate standards for diphacinone and brodifacoum, respectively. Diphacinone and brodifacoum concentrations were determined using an Agilent 1100 series HPLC system and Gemini C18, $3.0 \mu \mathrm{m}, 150 \times 3.0 \mathrm{~mm}$ column (Phenomenex). Brodifacoum and difenacoum were detected using fluorescence with an excitation wavelength of $273 \mathrm{~nm}$ and an emission wavelength of $390 \mathrm{~nm}$.

\subsection{Fecal occult blood tests}

Fecal samples were tested for the presence of blood in an attempt to determine if animals had clotting dysfunction without drawing blood. Fecal samples were tested using both Hemoccult and Hemoccult SENSA kits according to manufacturer's instructions (Beckman Coulter, Brea, CA, USA).

\subsection{Statistical methods}

\subsubsection{Anticoagulant residues}

We calculated means and standard errors of the means for residue levels of diphacinone and brodifacoum in livers and whole-body remainders for each species and dose. Residue values that fell below the method limit of detection (MLOD) were assigned a value of half the MLOD. ${ }^{23}$

\begin{tabular}{lcc} 
Table 4. & Behaviors and postures evaluated for each species \\
Species & $\begin{array}{c}\text { Behavior } \\
\text { tested }\end{array}$ & \multicolumn{1}{c}{ Posture tested } \\
\hline Ameiva & $\begin{array}{c}\text { Sleeping, } \\
\text { hiding, } \\
\text { basking } \\
\text { constrictors }\end{array}$ & $\begin{array}{c}\text { Curled up, on front legs, limbs near } \\
\text { body, limbs extended }\end{array}$ \\
$\begin{array}{l}\text { Boa } \\
\text { Curled up } \\
\text { Iguana }\end{array}$ & $\begin{array}{c}\text { Hiding, } \\
\text { basking }\end{array}$ & $\begin{array}{c}\text { Curled up, on front legs, limbs near } \\
\text { body }\end{array}$ \\
Turtle & Inactive, hiding & Alert, non-alert
\end{tabular}

\subsubsection{Behavioral/posture observations}

The potential impacts of toxicant treatments on body weights, behaviors, and postures noted throughout the study were assessed using linear mixed effects regression models. While many behaviors and postures were assessed, only variables with a high enough frequency to provide adequate statistical power were evaluated (Table 4). Each dependent variable (e.g. basking, curled up) was modeled as a function of several fixed effects: toxicant treatment (control, brodificoum, or diphacinone), dose $(0,1$, or 10), week (week 1 after the first dose was administered or week 2 after the second dose was administered), and sex. Because repeated measures were collected on individuals in different weeks, individual animal ID was included as a random effect. Interactions between treatment and dose (treatment*dose) and treatment and week (treatment or dose) were tested and retained if their inclusion reduced Akaike's Information Criterion.

\section{RESULTS}

\subsection{Acute toxicity}

Changes in weight were extremely variable across all groups, but there were no consistent patterns of weight loss in any species for any treatment group, suggesting that diet and animal care were adequate and health status did not affect toxicity outcomes (data not shown).

Administration of two gavage doses of diphacinone at the low dose did not result in mortality in any of the animals tested. One ameiva (female) in the high-dose diphacinone group died the day following its second gavage; however, we observed no hemorrhaging or coagulopathy on necropsy or in histopathological examination of the tissues. In iguanas, evidence of non-lethal internal and/or external hemorrhaging was observed in both low and high diphacinone groups (Table 5).

Three ameivas (two females, one male) and one iguana (male) in the low dose brodifacoum group died during the test period, but showed no obvious indications of anticoagulant intoxication. The one iguana mortality in the low dose brodifacoum group showed signs of anticoagulant intoxication with blood in the body cavity noted at necropsy. One ameiva (male) died in the high dose brodifacoum group but did not show any signs of anticoagulation intoxication. No post-dosing regurgitation was observed in any animals. Additionally, several iguanas in both treatment groups at both doses following treatment displayed markedly dark coloration, frequently considered a sign of stress. ${ }^{24}$ This change in coloration was not noted in any control animals. Similarly, several treated ameivas were notably lethargic or unresponsive following dosing, which again was not noted in controls.

\subsection{Tissue residue levels}

Residue levels of both brodifacoum and diphacinone were determined in liver and whole-body remainder (the entire carcasses without the liver and tissues removed for histopathology). In boas, ameivas, and iguanas brodifacoum levels were greater than diphacinone levels for both low and high doses in the whole-body remainder. Ameivas and iguanas had an almost 10-fold increase in residue levels between low and high dose brodifacoum in the whole-body remainder $\left(0.12\right.$ and $1.16 \mu \mathrm{g} \mathrm{g}^{-1}$ for ameivas, respectively; 0.18 and $1.57 \mu \mathrm{g} \mathrm{g}^{-1}$ for iguanas, respectively). Turtles had a 5 -fold increase in brodifacoum levels in the whole-body remainder between low and high doses $\left(0.09\right.$ and $0.48 \mu \mathrm{g} \mathrm{g}^{-1}$, respectively, Fig. 1). 
Table 5. Summary of the effects of diphacinone and brodifacoum dosing on four species of reptiles

\begin{tabular}{|c|c|c|c|c|c|c|c|c|}
\hline & \multicolumn{2}{|c|}{ Turtles } & \multicolumn{2}{|c|}{ Boa constrictors } & \multicolumn{2}{|c|}{ Ameivas } & \multicolumn{2}{|c|}{ Iguanas } \\
\hline & $\begin{array}{l}\text { Dead/ } \\
\text { dosed }\end{array}$ & Hemorrhaging & $\begin{array}{l}\text { Dead/ } \\
\text { dosed }\end{array}$ & Hemorrhaging & $\begin{array}{l}\text { Dead/ } \\
\text { dosed }\end{array}$ & Hemorrhaging & $\begin{array}{l}\text { Dead/ } \\
\text { dosed }\end{array}$ & Hemorrhaging \\
\hline Control & $0 / 8$ & 0 & $0 / 7$ & 0 & $0 / 9$ & 0 & $0 / 9$ & 0 \\
\hline Low diphacinone & $0 / 8$ & 0 & $0 / 8$ & 0 & $0 / 10$ & 0 & $0 / 9$ & $1 \mathrm{E}, 1 \mathrm{I}$ \\
\hline High diphacinone & $0 / 4$ & 0 & $0 / 8$ & 0 & $1 / 9$ & 0 & $0 / 10$ & $2 \mathrm{E}, 2 \mathrm{E} \& \mathrm{I}$ \\
\hline Low brodifacoum & $0 / 8$ & 0 & $0 / 8$ & 0 & $3 / 9$ & 0 & $1 / 9$ & $1 \mathrm{E}$ \\
\hline High brodifacoum & $0 / 4$ & 0 & $0 / 8$ & 0 & $1 / 9$ & 0 & $0 / 10$ & $1 \mathrm{E}$ \\
\hline
\end{tabular}

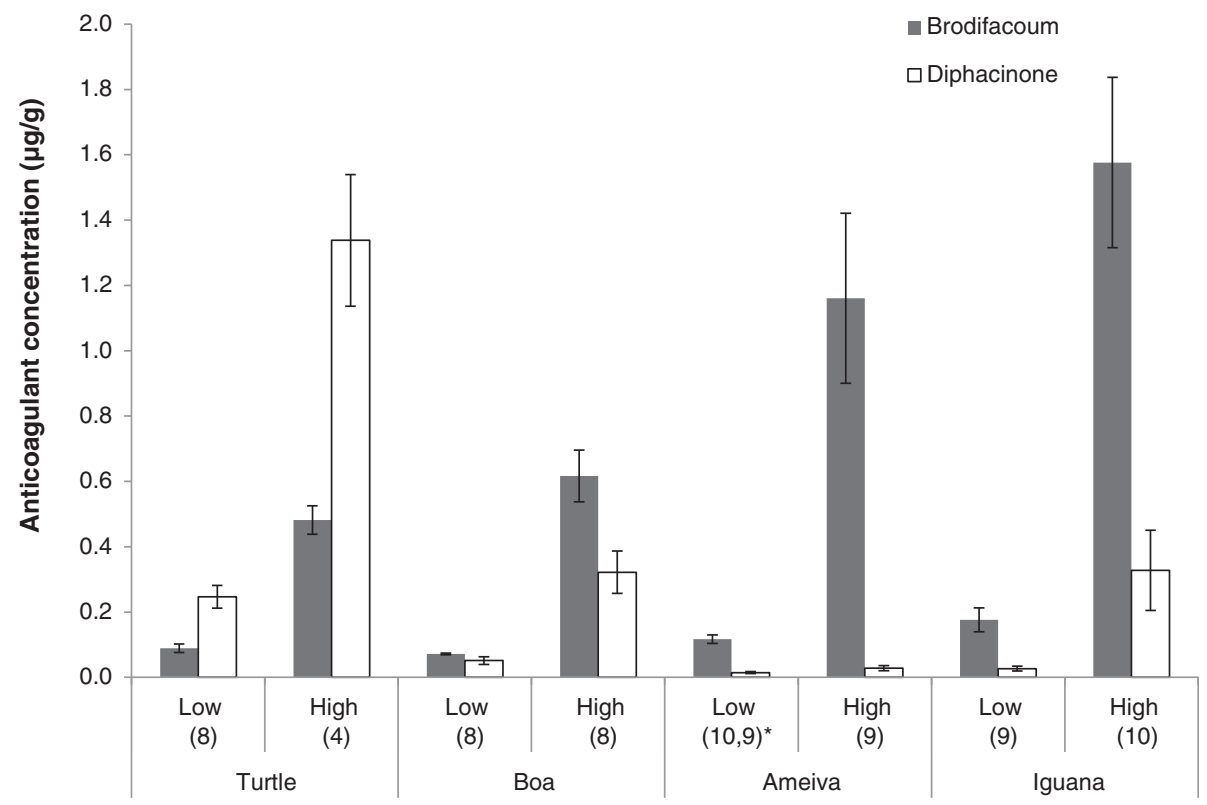

Figure 1. Residue levels found in whole-body remainder (carcasses without liver) from reptiles dosed with low or high levels of diphacinone or brodifacoum (mean \pm SEM, $\mu \mathrm{g} \mathrm{g}^{-1}$ ).

Contrary to the other species tested, turtles had greater diphacinone than brodifacoum levels in the whole-body remainder. For both low and high doses, turtles had more than 2.5 times higher diphacinone than brodifacoum residue levels in both high and low doses. Turtles also had lower residue levels in the whole-body remainder than all other species for high dose brodifacoum (Fig. 1).

Liver residue levels of brodifacoum and diphacinone were also tested. All liver samples from all species had higher residue levels than the whole-body remainder samples. Diphacinone levels in the livers from amevias were only slightly greater than the whole-body remainder residue levels (liver: low 0.127, high $0.096 \mathrm{\mu g} \mathrm{g}^{-1}$; whole-body remainder: low 0.015 , high $\left.0.028 \mu \mathrm{g} \mathrm{g}^{-1}\right)$. Livers from ameivas and iguanas had the highest brodifacoum residue concentrations $\left(6.37\right.$ and $3.51 \mu \mathrm{g} \mathrm{g}^{-1}$, respectively). Interestingly, turtles and boas had the highest liver diphacinone concentrations $\left(1.30\right.$ and $0.89 \mu^{-1} g^{-1}$, respectively) (Fig. 2).

\subsection{Histopathology}

We observed no histopathological anomalies and no animal exhibited any signs of treatment-related coagulopathy or microangiopathy.

\subsection{Fecal occult blood tests}

There were no positive detections of occult blood in any fecal sample from any of the species.

\subsection{Behavioral/posture observations}

\subsubsection{Model results}

Body weight did not vary over time in response to the different treatment and dose groups for any of the four species. Similarly, none of the behavioral variables tested showed significant differences between treatment groups. However, marginally significant results for one of the posture variables for ameivas and one for turtles were observed. Specifically, for ameivas, animals in the 10x brodificoum group exhibited the limbs near body posture $17 \%$ less frequently compared to controls $(P<0.04)$. Turtles in the diphacinone group were significantly more likely to be nonalert compared to turtles in the control and brodifacoum groups, and this difference was greater for turtles in the $1 \times$ group $(14 \%$ more than other treatment groups, $P<0.02$ ) than animals in the $10 \times$ diphacinone group ( $10 \%$ more than other treatment groups). Because nearly 20 behavioral and postural variables were tested, these relationships may be spurious (i.e. at a $P<0.05$ threshold 


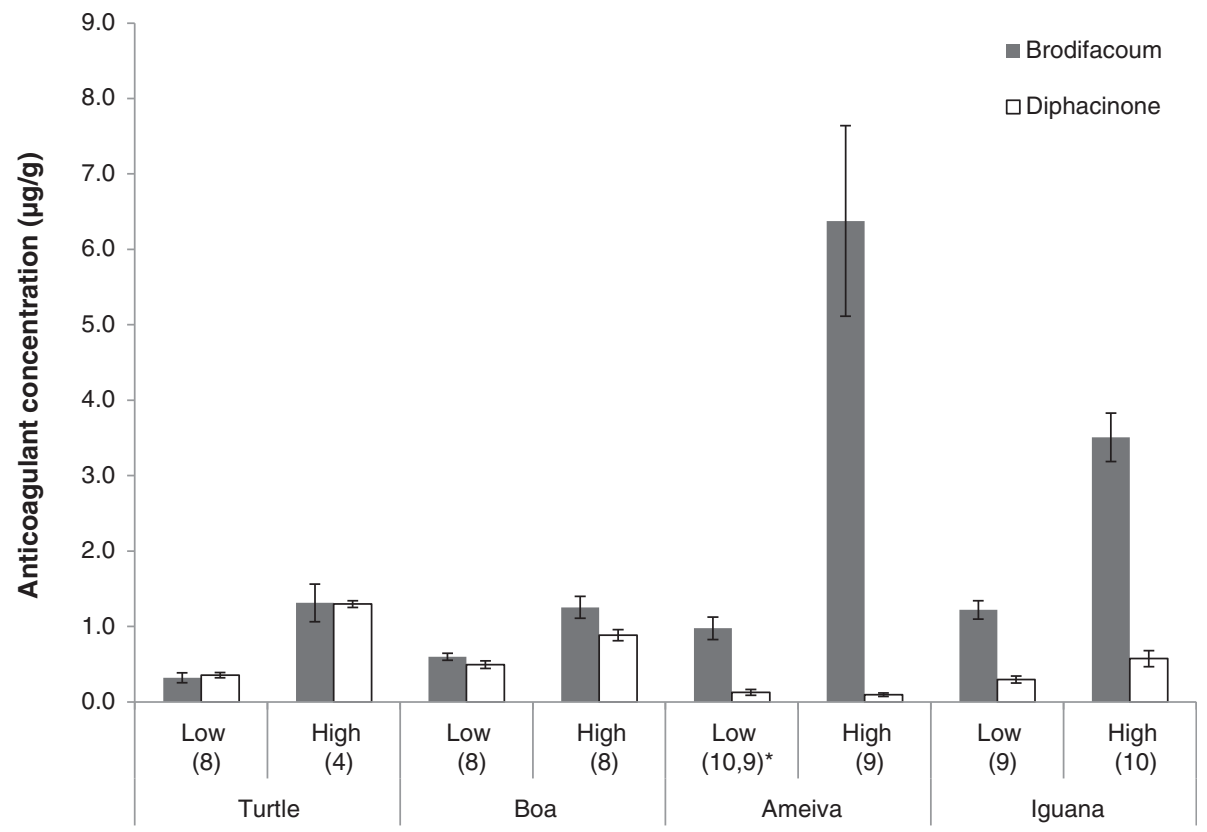

Figure 2. Residue levels found in liver tissue from reptiles dosed with low or high levels of diphacinone or brodifacoum (mean $\pm \mathrm{SEM}, \mu \mathrm{g} \mathrm{g}^{-1}$ ).

we would expect to get one significant result across 20 comparisons just by chance) and should only be considered as potential hypotheses for future study.

\section{DISCUSSION}

Neither diphacinone nor brodifacoum at either dose level caused mortality in turtles or boas, indicating a lower risk probability associated with exposure for either anticoagulant at the dosages tested. This is especially true since the high doses of both rodenticides represented ten times the amount administered in the low dose using generalized daily food intake estimates as an initial approach to dosage selection.

Across three of the treatment groups (Table 5), a few ameivas died during the study but showed no overt signs of internal or external bleeding during necropsy or histological examination. Several iguanas showed signs of anticoagulant intoxication, but none of those animals died, with the only exception being an iguana in the brodifacoum low dose group. This animal had coagulated blood on the tip of its nose and in its mouth as well as blood in the abdominal cavity. While anticoagulant-related hemorrhage is likely in this case, it seems problematic that a single animal in the low dose group would die when no iguanas in the high dose group did.

As described previously, hemorrhaging and microangiopathy were considered the most obvious signs of anticoagulant toxicity in the reptiles used in this study. In a few previous studies in which reptile carcasses were collected and necropsied following baiting operations, hemorrhaging was observed in some or all of the bodies. $^{14,15}$ Interestingly, Merton ${ }^{15}$ noted that in ten Telfair's skinks which had died following brodifacoum baiting operations on Round Island and subsequently analyzed, only one showed indications of internal hemorrhaging, and suggested that brodifacoum may have affected the lizards by unknown non-hemorrhagic means, perhaps through interference with thermoregulation.
Because of the paucity of literature addressing anticoagulant toxicity in reptiles, all the possible symptoms of anticoagulant toxicity in reptiles may not be known. In the current study, since no animals in the control group died, death in treated ameivas that exhibited no hemorrhaging suggests the possibility of nonhemorrhagic causes and indicates the need for further research into anticoagulant toxicity in these species.

Additionally, there were no significant effects of anticoagulants on the behaviors observed in this study. There were significant treatment effects on postures in both turtles (limbs near body less frequently) and ameivas (non-alert more likely), but the biological significance of these observations is not obvious and needs to be explored in future studies.

The majority of anticoagulant research has been done on mammals. However, there are significant differences in the clotting cascades of mammals and reptiles. Reptiles, and other poikilotherms, have noteworthy differences in physiology and specifically blood chemistry compared to their mammalian counterparts. There are numerous reports stating that clotting time in reptiles is greatly increased when compared to mammals. ${ }^{25-31}$ Although reptiles have the extrinsic clotting pathway, differences in many of the other factors have been reported. ${ }^{32}$ Spectacled caimans are missing factors V, VII, IX, and $\mathrm{XI}$ of the intrinsic (vitamin $\mathrm{K}$ dependent) pathway. ${ }^{33}$ Frost and colleagues ${ }^{30}$ reported that puff adders have reduced activity of prothrombin, $\alpha$-antiplasmin, and kallikrein compared to humans. These studies did not directly investigate the role that differences in clotting mechanisms may have in affecting susceptibility to anticoagulants; however, it seems likely that the physiological differences would alter a reptile's response to diphacinone and brodifacoum when compared to mammals. More research needs to be done to elucidate how these mechanistic changes in the clotting cascade alter the risks to reptiles associated with anticoagulant rodenticides.

Residue levels of diphacinone and brodifacoum in the reptiles in this study were similar to those reported in previous studies; however, the doses given to these reptiles were very high when 
compared to other studies. Pitt et $a l^{34}$ determined the diphacinone concentration in liver and muscle from feral swine fed diphacinone rodenticide bait. The diphacinone residue level they found, $1.733 \mu \mathrm{g} \mathrm{g}^{-1}$ in liver tissue, is similar to the turtle residue levels at the diphacinone high dose in this study. It is greater than the diphacinone residue levels found in all other species. The average muscle residue level in the Pitt et al. ${ }^{34}$ study of $0.209 \mu \mathrm{g} \mathrm{g}^{-1}$ is less than the turtle whole-body remainder residue levels found in this study, but comparable to the residue levels in the other species dosed at the diphacinone high level. Slugs (Limax maximus and Deroceras leave) and snails (Oxychilus spp.) that were offered diphacinone bait for 7 days had whole-animal residue levels in the range of residue levels found in all reptiles in this study (L. maximus $0.61 \mu^{g^{-1}}$, D. leave $0.23 \mu \mathrm{g} \mathrm{g}^{-1}$, Oxychilus spp $\left.0.69 \mu \mathrm{g} \mathrm{g}^{-1}\right){ }^{35}$

The brodifacoum residue levels found in this study were comparable to those found in previous studies. In a study of voles trapped in areas treated with brodifacoum bait, Merson et al. ${ }^{36}$ found residue levels of 2.07 and $4.07 \mu \mathrm{g} \mathrm{g}^{-1}$ depending on brodifacoum application rate. On days 2, 12, 34, and 210 following an aerial baiting of Lady Alice Island, samples of cockroaches (Blattidae), tree weta (Hemideina thoracica), cave weta (Gymnoplectron spp.), and black beetles (Coleoptera) were collected and analyzed for brodifacoum residues. No brodifacoum was detected in the tree weta, cockroaches, or black beetles, but $4.3 \mu \mathrm{g} \mathrm{g}^{-1}$ was found in the cave weta on the baits. ${ }^{37}$ Brodifacoum residue levels were greater than diphacinone levels in all species except turtles. In the whole-body remainder in turtles, diphacinone residue levels were 2.5 times greater than brodifacoum at both low and high dose levels. In liver tissues, the residue levels of diphacinone and brodifacoum were more similar. It is possible that these unusual findings are a result of different metabolic pathways in turtles.

The finding that, in general, these reptiles had residue levels comparable to mammal residue levels even though the reptiles received larger quantities of diphacinone and brodifacoum than most mammal studies warrants further consideration. These differences in residue levels may be a result of differences in metabolic pathways. In mammals, the cytochrome P-450 pathway is responsible for the metabolism of most anticoagulants. Although, in general, reptiles possess most of the same phase I metabolic enzymes as mammals, the amount cytochrome P-450 in reptiles is significantly lower than that found in mammals. ${ }^{38-40}$ Also, when compared to mammals, reptiles have been shown to have different cytochrome P-450 activity levels and the response of these enzymes to the presence of inducing compounds. ${ }^{38,41}$ Andersson and Nilsson ${ }^{39}$ found significant differences in cytochrome P-450 metabolism in their study of hag fish (Myxine glutinosa), dogfish (Scualus acanthias), perch (Perca fluvtatilis), and caiman (Caiman sclerops). It is possible that other phase I metabolic pathways are responsible for anticoagulant metabolism in reptiles, which may explain the variations in residue levels.

\section{CONCLUSION}

Compared with the lizards used in this study, the wood turtles and boas appear to be relatively insensitive to diphacinone and brodifacoum. No animals from either of these species showed overt hemorrhaging or any other signs of intoxication in response to anticoagulants. In contrast, internal and external hemorrhaging was found in iguanas dosed with low and high levels of diphacinone and brodifacoum, although only one iguana died due to likely intoxication.

In ameivas, the fact that several treated (but not control) animals died but showed no signs of any hemorrhaging or microangiopathy suggests that anticoagulants may exert effects other than inhibition of coagulation. Further research into anticoagulant toxicology in this species is clearly needed.

Brodifacoum residue levels in liver and whole-body remainder were higher in boas, ameivas, and iguanas while diphacinone levels were higher than brodifacoum levels in turtles. Hopefully, these results will be useful in the determination of non-target risks to these and related species associated with anticoagulant use in future rodent control operations.

\section{FUNDING}

This work was supported by Island Conservation (agreement No. 7485-0766-RA). The study was also supported by the intramural research program of the US Department of Agriculture (APHIS).

\section{ACKNOWLEDGEMENTS}

The authors wish to thank Jenna Keller, Chris Campton, and Celeste Samra for their help with experimental logistics, animal dosing, and data handling, NWRC animal care staff, specifically Steve Rogers, for their knowledge and expertise in reptile care and maintenance, and David Goldade and Steven Blamer for the chemical analysis of samples. Mention of a commercial product or company does not represent endorsement by the federal government.

\section{COMPETING INTERESTS}

All authors declare no competing interests.

\section{AUTHOR CONTRIBUTION STATEMENT}

REM and $\mathrm{KH}$ designed and conducted the study, and wrote the manuscript with significant assistance from RSM. SS performed the majority of the statistical analysis, and GW participated in experimental design, execution, and manuscript review.

\section{REFERENCES}

1 Howald G, Donlan CJ, GalvÁN JP, Russell JC, Parkes J, Samaniego A et al., Invasive rodent eradication on islands [Erradicación de roedores invasores de islas]. Conserv Biol 21:1258-1268 (2007).

2 Witmer GW, Boyd F and Hillis-Starr Z, The successful eradication of introduced roof rats (Rattus rattus) from Buck Island using diphacinone, followed by an irruption of house mice (Mus musculus). Wildl. Res 34:108-115 (2007).

3 Moors PJ and Atkinson IAE, Predation on seabirds by introduced animals, and factors affecting its severity (ICBP Technical Publication 2), New Zealand Wildlife Service, pp. 667-690 (1984).

4 Towns DR and Daugherty $\mathrm{CH}$, Patterns of range contractions and extinctions in the New Zealand herpetofauna following human colonisation. NZ J. Zool 21:325-339 (1994).

5 Witmer GW and Singleton G, Sustained agriculture: the need to manage rodent damage, in Rodents: Habitat, Pathology and Environmental Impacts, ed. by Triunveri A and Scalise D. Nova Science Publications, New York, NY, pp. 145-182 (2012).

6 Pitt WC, Berentsen AR, Shiels AB, Volker SF, Eisemann JD, Wegmann AS et al., Non-target species mortality and the measurement of brodifacoum rodenticide residues after a rat (Rattus rattus) eradication on Palmyra atoll, tropical Pacific. Biological Conservation 184:36-46 (2015). 
7 Vietch CR and Clout MN, Turning the tide: the eradication of invasive species, in Proceedings of the International Conference on Eradication of Island Invasives, ed. by Vietch CR and Clout MN. Occasional Paper of the IUCN Species Survival Commission No. 27 (2002).

8 Albert CA, Wilson LK, Mineau P, Trudeau S and Elliott JE, Anticoagulant rodenticides in three owl species from Western Canada, 1988-2003. Arch Environ Contam Toxicol 58:451-459 (2010).

9 Eason CT and Spurr EB, Review of the toxicity and impacts of brodifacoum on non-target wildlife in New Zealand. NZ J. Zool 22: 371-379 (1995)

10 Howald GR, Mineau P, Elliott JE and Cheng KM, Brodifacoum poisoning of avian scavengers during rat control on a seabird colony. Ecotoxicology 8:431-447 (1999).

11 Lambert $\mathrm{O}$, Pouliquen $\mathrm{H}$, Larhantec $\mathrm{M}$, Thorin $\mathrm{C}$ and L'Hostis $\mathrm{M}$, Exposure of raptors and waterbirds to anticoagulant rodenticides (difenacoum, bromadiolone, coumatetralyl, coumafen, brodifacoum): epidemiological survey in Loire Atlantique (France). Bull Environ Contam Toxicol 79:91-94 (2007).

12 Stone WB, Okoniewski JC and Stedelin JR, Poisoning of wildlife with anticoagulant rodenticides in New York. J Wildl Dis 35:187-193 (1999).

13 Tocher M, Summary: Effects of 1080 and Anti-Coagulants on Lizards. From the website NZWildlifeManagement. (2008). Available: $\mathrm{http} / / / \mathrm{www} w i l d$ lifemanagementnetnz/indexphp?topic= $530[\mathrm{xx} x \mathrm{xxx}]$.

14 Merton D, Eradication of rabbits from Round Island, Mauritius: a conservation success story. Dodo 24:19-43 (1987).

15 Bettink K, Control and eradication of black rats (*Rattus rattus) on Penguin Islaand, Western Australia, December 2012-December 2014, in Natural History and Management of the Shoalwater Islands and Marine Park: Proceedings of a Seminar. Point Peron Camp School, Department of Parks and Wildlife, Perth (2015).

16 Sanchez-Barbudo IS, Camarero PR and Mateo R, Primary and secondary poisoning by anticoagulant rodenticides of non-target animals in Spain. Sci Total Environ 420:280-288 (2012).

17 Hoare JM and Hare KM, The impact of brodifacoum an non-target wildlife: gaps in knowledge. NZ J Ecol 30:157-167 (2006).

18 Lohr MT and Davis RA, Anticoagulant rodenticide use, non-target impacts and regulation: a case study from Australia. Sci Total Environ 634:1372-1384 (2018).

19 Herrera Jl, Figuerola-Hernandez CE, Holmes ND, Swinnerton K Bermudez-Carambot EN, Fonzales-Maya JF et al., Survival analysis of two endemic lizard species before, during, and after a rat eradication attempt on Desecheo Island, Puerto Rico, in Island Invasives: Scaling up to Meet the Challenge. Occasional Paper SSC no 62, ed. by Veitch CR, Clout MN, Martin AR, Russell JC and West CJ. IUCN, Gland, pp. 191, 191-195, 195 (2019).

20 Brooks JE, Savarie PJ and Johnston JJ, The oral and dermal toxicity of selected chemicals to brown tree snakes (Boiga irregularis). Wildl Res 25:427-435 (1998).

21 Freeman AB, Kickling GL and Bannock CA, Responses of the Native Skink Leiolopisma Maccanni to Two Pest Control Baits, Conservation Advisory Science Notes 139, Department of Conservation, Wellington, (1995).

22 Nagy KA, Field metabolic rate and food requirement scaling in mammals and birds. Ecol Monogr 57:111-128 (1987).
23 US Enviromental Protection Agency OoPP, Assigning Values to Nondetected/Non-quantified Pesticide Residues in Human Health Food Exposure Assessments, Office of Pesticide Programs, U.S. Environmental Protection Agency, Washington, DC 20460 (2000).

24 Lewis AC, Rankin KJ, Pask AJ and Stuart-Fox D, Stress-induced changes in color expression mediated by iridophores in a polymorphic lizard. Ecol Evol 7:8262-8272 (2017).

25 Brambel CE, Prothrombin activity of turtle blood and the effect of a synthetic vitamin K derivative. J Cell Comp Physiol 18:221-232 (1941).

26 Fantl P, A comparative study of blood coagulation in vertebrates. Aust J Exp Biol Med 39:403-412 (1961).

27 Hackett E and Hann C, Slow clotting of reptile bloods. J Comp Pathol 77:175-180 (1967).

28 Denson KW, The clotting of a snake (Crotalus viridis Helleri) plasma and its interaction with various snake venoms. Thromb Haemost 35: 314-323 (1976).

29 Nahas L, Kamiguti AS, Betti F, Sano Martins IS and Rodrigues MI, Blood coagulation mechanism in the snakes Waglerophis merremii and Bothrops jararaca. Comp Biochem Physiol Part A 69:739-743 (1981).

30 Frost CL, Naude RJ, Oelofsen W and Jacobson B, Comparative blood coagulation studies in the ostrich. Immunopharmacology 45:75-81 (1999).

31 Kubalek S, Mischke R and Fehr M, Investigations on blood coagulation in the green iguana (Iguana iguana). J Vet Med A 49:210-216 (2002).

32 Spurling NW, Comparative physiology of blood clotting. Comp Biochem Physiol Part A 68:541-548 (1981).

33 Arocha-Piñango $\mathrm{CL}$, Gorzula SJ and O A, The blood clotting mechanism of spectacled caiman Caiman crocodilus. Mol Physiol 2:161-170 (1982).

34 Pitt WC, Higashi M and Primus TM, The effect of cooking on diphacinone residues related to human consumption of feral pig tissues. Food Chem Toxicol 49:2030-2034 (2011).

35 Johnston JJ, Pitt WC, Sugihara RT, Eisemann JD, Primus TM, Holmes MJ et al., Probalistic risk assessment for snails, slugs, and endangered honeycreepers in dephacinone rodenticide baited ares on Hawaii, USA. Environ Toxicol Chem 24:1557-1567 (2005).

36 Merson MH, Byers RE and Kaukeinen DE, Residues of the rodenticide brodifacoum in voles and raptors after orchard treatment. $J$ Wildl Manag 48:212-216 (1984).

37 Ogilvie SC, Pierce RJ, Wright GRG, Booth LH and Eason CT, Brodifacoum residue analysis in water, soil, invertebrates, and birds after rat eradication on Lady Alice Island. NZ J Ecol 21:195-197 (1997).

38 Ertl RP and Winston GW, The microsomal mixed function oxidase system of amphibians and reptiles: components, activities and induction. Comp Biochem Physiol C Pharmacol Toxicol Endocrinol 121: 85-105 (1998).

39 Andersson $\mathrm{T}$ and Nilsson E, Characterization of cytochrome P450-dependent activities in hagfish, dogfish, perch and spectacle caiman. Comp Biochem Physiol B 94:99-105 (1989).

40 Jewell CS, Cummings LE, Ronis MJ and Winston GW, The hepatic microsomal mixed-function oxygenase (MFO) system of Alligator mississippiensis: induction by 3-methylcholanthrene (MC). Xenobiotica 19:1181-1200 (1989).

41 Walker $\mathrm{CH}$ and Ronis MJ, The monooxygenases of birds, reptiles and amphibians. Xenobiotica 19:1111-1121 (1989). 